\title{
PELAKSANAAN ALOKASI DANA DESA (ADD) DALAM BIDANG PEMBERDAYAAN MASYARAKAT DI KABUPATEN KONAWE
}

\author{
Oleh: \\ Jopang $^{1}$, Arifin Utha ${ }^{2}$, Eko Harianto ${ }^{3}$ \\ 1,2Dosen Jurusan Administrasi Publik Fakultas Ilmu Sosial dan Ilmu Politik UHO \\ ${ }^{3}$ Dosen Jurusan Komunikasi Pertanian Fakultas MIPA Universitas Terbuka \\ jopangopang@yahoo.co.id
}

\begin{abstract}
The shift in the principle of setting of the principle of "decentralization" and "residuals" on previous legislation became the principle of subsidiarity and the principle of recognizing in Act No. 6 of the year 2014 of the village became hope and renewed energy for the village to be able to determine the position, role and authority over him. This research aims to analyze the implementation of the budget of the village Fund in the field of community empowerment in Wowonii Island.
\end{abstract}

This research uses qualitative descriptive approach. The subject specified in purposive that describe the representation of topology village (the region of mainland coast, and inland). The technique of data collection was done through interviews, the study document, Focus Group Discussions and observations. The technique of data analysis performed with the interactive approach in the form of model reduction data, display data, verification and conclusion.

The results of showing the budget of the village during the time brackets 4 (four) years have contributed to the village and community in the County Wowonii Island. Although the budget of the fund of the village in the field of development and the empowerment of the community very small but their impact is very beneficial for community interests. The Village Government and the Improved Quality in 2014 The Village Government and the Improved Quality in 2014, the Village Fund Budget Year 2014, 2015 and 2016, do not contribute directly to the community. of community service. The village Fund Budget activity 2015-2017 year, especially through the village of interior Shield, is considered to be highly contributing to society, especially the poor and women. Surgical program home and Businesses Productive is the flagship program of the community throughout the village District Wowonii Island.

Keywords: Implementation, Allocation Of The Village Fund, Community Empowerment 


\section{PENDAHULUAN}

UU Desa telah menempatkan desa sebagai organisasi campuran (hybrid) antara masyarakat berpemerintahan (self governing community) dengan pemerintahan lokal (local self government). Dengan begitu, sistem pemerintahan di desa berbentuk pemerintahan berbasis masyarakat dengan segala kewenangannya (authority). Desa juga tidak lagi identik dengan pemerintah desa dan kepala desa, melainkan pemerintahan desa yang sekaligus pemerintahan masyarakat yang membentuk kesatuan entitas hukum. Artinya, masyarakat juga mempunyai kewenangan dalam mengatur desa sebagaimana pemerintahan desa. Kewenangan merupakan elemen penting sebagai hak yang dimiliki oleh desa untuk dapat mengatur rumah tangganya sendiri.

Kewenangan merupakan elemen penting sebagai hak yang dimiliki oleh sebuah desa untuk dapat mengatur rumah tangganya sendiri. Menurut pasal 18 UU Nomor 6 tahun 2014 tentang Desa, Kewenangan desa meliputi kewenangan di bidang penyelenggaraan pemerintahan desa, pelaksanaan pembangunan desa, pembinaan kemasyarakatan desa dan pemberdayaan masyarakat desa berdasarkan prakarsa masyarakat, hak asal-usul dan adat istiadat desa. Selanjutnya pasal 19, kewenangan desa meliputi : (a) Kewenangan berdasarkan hak asal-usul; (b) Kewenangan lokal berskala desa; (c) Kewenangan yang ditugaskan oleh Pemerintah, Pemerintah Daerah Propinsi, atau Pemerintah Daerah Kabupaten/Kota; (d) Kewenangan lain yang ditugaskan oleh Pemerintah, Pemerintah Daerah Propinsi, atau Pemerintah Daerah Kabupaten/Kota sesuai dengan ketentuan peraturan perundang-undangan.

Kewenangan yang dimiliki oleh desa untuk mengurus dan mengatur warganya merupakan bentuk kewenangan yang diberikan oleh pemerintah pusat untuk mengurus dirinya sendiri (otonomi desa) dengan tujuan agar tercipta kesejahteraan bagi warganya. Sebagai konsekuensi logis adanya kewenangan dan tuntutan dari pelaksanaan otonomi desa adalah tersedianya dana yang cukup. Menurut Wasistiono, S (2006 : 107) pembiayaan atau keuangan merupakan faktor essensial dalam mendukung penyelenggaraan otonomi desa, sebagaimana penyelenggaraan otonomi daerah. Untuk mengatur dan mengurus rumah tangganya sendiri desa membutuhkan dana atau biaya yang memadai sebagai dukungan pelaksanaan kewenangan yang dimiliki oleh desa. Dengan adanya kewenangan yang dimiliki oleh desa diharapkan menjadi instrumen dan solusi yang tepat untuk mewujudkan akselerasi pembangunan di desa. meskipun harus diimbangi dengan daya dukung lainnya seperti kemampuan dan mentalitas aparatur pemerintah desa maupun sikap responsif masyarakat desa untuk secara konstruktif dan bertahap berupaya meningkatkan kesejahteraannya.

Untuk menunjukkan eksistensi desa sebagai bagian dari pemerintah langkah awalnya adalah dengan memberikan kewenangan kepada desa untuk mengelola keuangannya sendiri melalui pemberian Alokasi Dana Desa (ADD) yang dilakukan oleh pemerintah daerah. Pemberian ADD kepada desa tentunya harus dibarengi dengan peningkatan kapasitas pemerintah agar dapat mengelola ADD tersebut tepat sasaran. Peningkatan kapasitas tersebut diberikan dalam rangka penguatan kewenangan yang dimiliki oleh Desa, dimana salah satunya adalah kewenangan pemberdayaan kepada masyarakat. Pemberdayaan masyarakat adalah proses yang berjalan terus menerus untuk meningkatkan kemampuan dan kemandirian masyarakat dalam meningkatkan taraf hidupnya (Hasan, 2002:56-57)

Pelaksanaan ADD di Kabupaten Konawe telah berlangsung sejak Kepempimpinan Bupati Konawe Dr. H. Lukman Abunawas, S.H, M.Si dengan mengeluarkan Peraturan Daerah Kabupaten Konawe Nomor 8 tahun 2009 tentang Alokasi Dana Desa. Dalam Pasal 12 (1) dijelaskan indikator keberhasilan ADD adalah sebagai berikut : (a). Meningkatnya pengetahuan masyarakat tentang ADD dan penggunaannya; (b). Meningkatnya partisipasi masyarakat dalam Musrembang Desa dan pelaksanaan pembangunan Desa;(c). Terjadinya sinergi antara kegiatan yang dibiayai ADD dengan program-program pemerintahan lainnya yang ada di Desa;(d).

Meningkatnya swadaya masyarakat Desa; (e). Tingkat penyerapan tenaga kerja lokal pada kegiatan 
pembangunan Desa; (f).Jumlah kelompok masyarakat penerima manfaat (terutama warga masyarakat miskin); dan (g).Terjadinya peningkatan pendapatan asli Desa;

Selanjutnya pasal 12 (2) Penggunaan Alokasi Dana Desa (ADD) adalah 30\% (tiga puluh per seratus) untuk belanja aparatur dan operasional, sedangkan 70\% (tujuh puluh per seratus) untuk biaya pemberdayaan masyarakat dan publik. Biaya pemberdayaan masyarakat dan publik tersebut digunakan untuk : (l) biaya perbaikan sarana publik dalam skala kecil; (2). Penyertaan modal usaha masyarakat melalui Badan Usaha Milik Desa (BUMDesa); (3) Biaya untuk pengadaan ketahanan pangan; (4) Perbaikan lingkungan dan pemukiman; (5) Teknologi Tepat Guna; (6). Perbaikan kesehatan dan pendidikan; (7) Pengembangan sosial budaya; (8) dan sebaginya yang dianggap perlu.

Pelaksanaan ADD setiap tahunnya selalu berpedoman pada Peraturan Bupati Konawe. Pada tahun 2014 mengacu pada Peraturan Bupati Nomor Nomor 6 tahun 2014 tentang Petunjuk Teknis Pelaksanaan Alokasi Dana Desa Tahun Anggaran 2014, bahwa total Alokasi Dana Desa (ADD) pada tahun 2014 di Kabupaten Konawe sebesar Rp. 22,017,520,000,- untuk 280 desa. Sementara tahun 2015 Pelaksanaan Alokasi Dana Desa diatur dalam Peraturan Bupati Konawe Nomor 3 A tahun 2015 tentang Petunjuk Teknis Pelaksanaan Alokasi Dana Desa Tahun Anggaran 2015. Pagu Alokasi Dana Desa (ADD) sedikit mengalami penurunan jika dibandingkan dengan tahun 2014. Pada tahun 2015 Pagu ADD sebesar Rp. 22,017,476,000,- dengan jumlah desa bertambah 3 desa menjadi 283 desa. Pada tahun 2016, porsi anggaran untuk kegiatan pemberdayaan masyarakat dan pembangunan juga semakin meningkat seiring dengan meningkatnya pagu Alokasi Dana Desa. Untuk desa kategori pertama yaitu desa yang mendapat dana transfer APBN, porsi anggaran untuk pemberdayaan masyarakat dan pembangunan secara keseluruhan mencapai 759,500,000,- untuk 220 desa. Pada tahun 2017 dasar hukum pelaksanaan ADD di Kabupaten Konawe adalah Peraturan Bupati Konawe Nomor 11 tahun 2017. Nilai ADD tahun 2017 sebesar Rp. 56.655.142.640,-

Berdasarkan kondisi tersebut di atas, penelitian ini diarahkan untuk melakukan kajian terhadap kontribusi ADD dalam bidang pemberdayaan masyarakat dan pembangunan desa di Kabupaten Konawe.

\section{KAJIAN TEORI}

\section{Konsep Pelaksanaan}

Pelaksanaan adalah suatu tindakan atau pelaksanaan dari sebuah rencana yang sudah disusun secara matang dan terperinci, implementasi biasanya dilakukan setelah perencanaan sudah dianggap siap. Wahab (2008:68) merumuskan proses pelaksanaan (implementasi) adalah pelaksanaan keputusan kebijakan dasar, biasanya dalam bentuk undang-undang, namun dapat pula berbentuk perintah atau keputusan badan eksekutif yang penting ataupun keputusan peradilan. Pengertian-pengertian di atas memperlihatkan bahwa kata pelaksanaan bermuara pada aktivitas, adanya aksi, tindakan, atau mekanisme suatu sistem. Ungkapan mekanisme mengandung arti bahwa pelaksanaan bukan sekedar aktivitas, tetapi suatu kegiatan yang terencana dan dilakukan secara sungguh-sungguh berdasarkan norma tertentu untuk mencapai tujuan kegiatan.

\section{Konsep Allokasi Dana Desa}

Undang-Undang Nomor 6 Tahun 2014 tentang Desa mengamanatkan pemerintah desa untuk lebih mandiri dalam mengelola pemerintahan dan berbagai sumber daya alam yang dimiliki, termasuk di dalamnya pengelolaan keuangan dan kekayaan milik desa. Keuangan Desa menurut Permendagri No. 113 Tahun 2014 adalah semua hak dan kewajiban desa yang dapat dinilai dengan uang serta segala sesuatu berupa uang dan barang yang berhubungan dengan pelaksanaan hak dan kewajiban desa.Sementara itu pengelolaan keuangan desa adalah seluruh rangkaian kegiatan yang dimulai dari tahap perencanaan, 
pelaksanaan, penatausahaan, pelaporan hingga pertanggungjawaban yang dilaksanakan dalam satu tahun anggaran, terhitung mulai 1 Januari sampai dengan 31 Desember.

Peraturan Pemerintah Republik Indonesia Nomor 47 Tahun 2015 Tentang Perubahan Atas Peraturan Pemerintah Nomor 43 Tahun 2014 Alokasi Dana Desa, selanjutnya disingkat ADD, adalah dana perimbangan yang diterima kabupaten/kota dalam anggaran pendapatan dan belanja daerah kabupaten/kota setelah dikurangi Dana Alokasi Khusus. Menurut Eka Putra (2018) Alokasi Dana Desa (ADD) merupakan salah satu bentuk hubungan keuangan antar tingkat pemerintahan yaitu hubungan keuangan antara pemerintah Kabupaten dengan Pemerintah Desa. Untuk dapat merumuskan hubungan keuangan yang sesuai maka diperlukan pemahaman mengenai kewenangan yang dimiliki pemerintah desa.

Kebiajak ADD diberikan kepada desa untuk memberikan ruang yang lebih besar bagi desa agar dapat menyelenggarakan urusan pemerintahan yang menjadi kewenangan desa dan untuk meningkatkan pelayanan serta pemberdayaan masyarakat desa. Pemberian Alokasi Dana Desa (ADD) kepada desa karena didasari oleh beberapa kendala besar desa mengalami keterbatasan dalam keuangan desa, sehingga program Alokasi Dana Desa (ADD) adalah terobosan dalam upaya penyelenggaraan pemerintahan desa dan pemberdayaan masyarakat desa secara terpadu. Hudayana (2005) menjelaskan ada empat faktor utama yang menyebabkan lahirnya ADD, yaitu : (l). Desa memiliki APBDes yang kecil dan sumber pendapatannya sangat tergantung pada bantuan yang sangat kecil pula; (2). Kesejahteraan masyarakat desa rendah; (3). Rendahnya dana operasional desa untuk menjalankan pelayanan; dan (4). Banyak program pembangunan yang masuk ke desa tetapi kebanyakan dikelola oleh dinas-dinas.

\section{Konsep dan Teori Pemberdayaan}

Secara etimologis pemberdayaan berasal dari kata dasar "daya" mendapat awalan ber menjadi kata berdaya, artinya memiliki dan mempunyai daya. Daya artinya kekuatan, berdaya artinya memiliki kekuatan. Jadi pemberdayaan artinya membuat sesuatu menjadi berdaya atau mempunyai daya atau mempunyai kekuatan (Hurairah, 2008:82). Bertolak dari pengertian di atas pemberdayaan dapat dimaknai sebagai sesuatu proses menuju berdaya, atau proses untuk memperoleh kekuatan/kemampuan, dan atau proses pemberian kekuatan/kemampuan. Pemberdayaan dapat bergerak dari pihak yang berdaya tetapi dapat pula sebaliknya yaitu bergerak dari pihak yang kurang/tidak berdaya.

Rappaport dalam Fahrudin (2012:16) mengartikan empowerment sebagai suatu cara dimana rakyat, organisasi dan komunitas diarahkan agar dapat berkuasa atas kehidupannya. Pemberdayaan masyarakat merupakan serangkaian upaya untuk menolong masyarakat agar lebih berdaya dalam meningkatkan sumber daya manusia dan berusaha mengoptimalkan sumber daya tersebut sehingga dapat meningkatkan kapasitas dan kemampuannya dalam memanfaatkan potensi yang dimilikinya sekaligus dapat meningkatkan kemampuan ekonominya melalui kegiatan-kegiatan swadaya.

Winarni (2008:75-76) mengemukakan bahwa inti dari pemberdayaan adalah mencakup 3 hal, yaitu : (l). memungkinkan (enabling), (2). memperkuat potensi atau daya (empowering) dan (3). Terciptanya kemandirian. Jadi pada hakekatnya pemberdayaan merupakan penciptaan suasana atau iklim yang memungkinkan potensi masyarakat berkembang (enabling). Sementara menurut Suhendra (2006:74-75) mendefinisikan pemberdayaan suatu kegiatan yang berkesinambungan dinamis secara strategis mendorong keterlibatan semua potensi yang ada secara evolutif dengan keterlibatan semua potensi.

Berdasarkan uraian definisi di atas dapat disimpulkan bahwa pemberdayaan adalah suatu upaya untuk membangkitkan sumber daya individu dan organisasi ke arah kemandirian untuk mewujudkan keadilandan kesejahteraan. 


\section{METODE PENELITIANN}

Penelitian ini menggunakan pendekatan deskriptif kualitatif. Menurut Sugiyono (2012) Data kualitatif adalah data yang berbentuk kata, kalimat, skema dan gambar. Subjek penelitian ditentukan secara purposif yang menggambarkan keterwakilan wilayah. Dalam penelitian ini wilayah sasaran peneliian dilakukan berdasarkan letak geografis dan tiplologi desa. Berdasarkan letak geografis terdiri dari desa pesisir pantai, daratan dan pedalaman. Sedangkan berdasarkan tiplolgi Desa dibagi berdasarkan desa agrobisnis, desa agroindustri, desa parawisata dan desa non pertanian (Adisamita, 2006). Penentuan wilayah sasaran penelitian tersebut dilakukan di semua wilayah Kecamatan yang ada di Kabupaten Konawe berjumlah 27 Kecamatan. Setiap kecamatan diambil Desa sasaran dengan mempertimbangkan letak geografis dan tiplogi desa tersebut.

Informan penelitian ini terdiri dari para pihak yang terkait langsung maupun tidak langsung seperti DPMPD Kabupaten Konawe, BAPPEDA Kabupatane Konawe, BPKAD Kabupaten Konawe, Sekretariat Daerah Kabupaten Konawe, Para Camat, Kepala Seksu, Para Kepala Desa, Tim Pengelola Kegiatan, BPD, dan masyarakat. Sumber data penelitian ini terdiri dari data primer dan data sekunder. Data primer diperoleh dari informan (instansi, pengelola kegiatan dan masyarakat) dengan teknik wawancara dan FGD. Sedangkan data sekunder diperoleh melalui studi dokumen seperti Dokuemn Perencanaan (RPJMDesa dan RKP), Dokumen Penganggaran (APBDesa dan RAB), Berita Acara Rapat, Laporan Pertanggungjawaban Kepala Desa serta dokumentasi kegiatan.

Teknis analisis data dilakukan dengan pendekatan Milles and Huberman (1987) dengan model interaktif melalui 4 (empat) kegiatan yaitu : (1). Data collection; (2). Data reduction (3). Data display; dan (4) conclusion/verivication.

\section{HASIL DAN PEMBAHASAN}

\section{PELAKSANAAN ADD}

Dasar hukum pelaksanaan ADD di Kabupaten Konawe setiap tahunnya selalu berpedoman pada Peraturan Bupati (Perbup) Konawe Nomor 06 tahun 2014 tentang Petunjuk Teknis Pelaksanaan ADD Tahun 2014, Perbup Konawe Nomor 3A tahun 2015, Perbup Konawe Nomor 5 tahun 2016 dan Perbup Konawe Nomor 11 tahun 2017.

Pengelolaan dilaksanakan oleh Tim Pelaksana Teknis. Tahun 2014, 2015 dan 2016, Tim Pelaksana Pengelolaan Alokasi Dana Desa terdiri dari unsur Perangkat Desa dan unsur masyarakat yang ditetapkan dengan Keputusan Kepala Desa. Susunan Tim Pelaksana terdiri dari : (a). Penanggung Jawab adalah Kepala Desa; (b). Ketua Tim Pelaksana adalah Sekretaris Desa; (c). Bendahara adalah Bendahara Desa dan (d) Anggota adalah Unsur Masyarakat

Hasil penelitian terkait dengan kelembagaan tersebut menunjukkan bahwa susunan tim pelaksana pengelolaan ADD pada tahun 2014, 2015 dan 2016 berdasarkan susunan yang tercantum dalam Peraturan Bupati setiap tahunnya. Hal ini dapat dilihat dari hasil wawancara dengan Camat Soropia berikut ini :

Tim pelaksana pengelola Alokasi Dana Desa di setiap Desa yang ada di Kabupaten Konawe selalu berdasarkan pada Peraturan Bupati Konawe yang terbit setiap tahunnya. Komposisi Tim Pelaksana terdiri dari Penanggung jawab adalah Kepala Desa, Ketua Tim Pelakana Sekretaris Desa, Bendahara adalah Bendahara Desa dan anggota 1 orang berasal dari perwakilan unsur masyarakat. Misalnya Di Desa Sawapudo Penanggung jawab adalah Armin selaku Kepala Desa Sawaudo, Supardin selaku Sekretaris Desa Sawapudo sebagai Ketua Tim Pelaksana, Jusran selaku Bendahara Desa sebagai Bendahara Kegiatan dan Abdul Khalik, S.Pd selaku anggota 
merupakan perwakilan dari unsur masyarakat (wawancara, 3 Oktober 2017).

Pernyataan Camat Soropia tersebut dibenarkan oleh Kades Sawapudo Armin dan Ketua BPD Sawapudo Muhammad Kasim S,Ag mengenai susunan tim personalia pengelolaan ADD di Desa. Demikian pula di Kecamatan Wonggeduku di Desa Polandangi Tim Pengelola ADD Penanggung jawab adalah Ahmad Arifuddin selaku Kades Polandangi, Yuliana sebagai Ketua Tim Pelaksana, Samset Binaris sebagai Bendahara Desa dan Amirullah sebagai anggota dari unsur masyarakat. Pendapat tersebut didukung pula oleh pernyataan Ketua BPD Desa Polandangi Ibu Hatna bahwa semua komposisi tim pengelola ADD berpatokan pada Peraturan Bupati Konawe yang ada setiap tahunnya.

Tim Pelaksana Desa secara bersama-sama menatausahakan semua proses kegiatan perencanaan, pelaksanaan kegiatan, pertanggungjawaban dan pelaporan penggunaan ADD. Tahun 2017, Pengelola ADD dilaksanakan oleh Pelaksana Teknis Pengelolaan Keuangan Desa (PTPKD) yang terdiri dari unsur Perangkat Desa yang ditetapkan dengan Keputusan Kepala Desa. Susunan Pelaksana Teknis Pengelolaan Keuangan Desa (PTPKD) terdiri atas : (a). Ketua adalah Sekretaris Desa; (b). Sekretaris adalah Kepala Seksi Pemerintahan dan (c). Bendahara adalah Bendahara Desa.

Berdasarkan hasil wawancara dengan Kasi Ekonomi BAPPEDA Kabupaten
Konawe terungkap bahwa kelembagaan Pengelolaan Alokasi Dana Desa di
Kabupaten Konawe setiap tahunnya adalah sebagai berikut : "Kelembagaan
Pengelolaan Alokasi Dana Desa mulai dari tingkat Desa disebut dengan
Pelaksana Teknis Pengelolaan Keuangan Desa (PTPKD). Untuk tingkat
Kabupaten disebut Tim Fasilitasi Tingkat Kabupaten yang bertanggung jawab
dalam pengelolaan ADD yang ditetapkan dengan Keputusan Bupati. Susunannya
terdiri dari : Bupati Konawe sebagai Pembina, Sekda Kabupaten Konawe sebagai
pengarah, Kepala Dinas DPMD Kabupaten Konawe selaku Ketua Tim, Kepala
Bidang Pemerintahan Desa Kabupaten Konawe sebagai Sekretaris Tim, Asisten I
bidang Tata Praja (Pemerintahan), Kepala BAPPEDA Kabupaten Konawe,
Kepala BPKAD, Kepala Inspektorat dan Kabag Hukum Setda Kabupaten Konawe
masing-masing sebagai anggota. BAPPEDA sebagai salah satu anggota tim
fasilitasi Kabupaten berperan dalam kaitannya dengan Tupoksinya menfasilitasi
Perencanaan Desa melalui Musrembang Kabupaten. Hasil Musrembang
Kabupaten tersebut diselaraskan dengan Hasil musrembang desa. setelah ada
penyelarasan musrembang Kabupaten dengan musrembang Desa selanjutnya
Desa mewujudkannya dalam RPJM Desa untuk jangka waktu 6 (enam) tahun.
Hasil RPJM Desa tersebut dituangkan dalam Rencana Kerja Pemerintah Desa
setiap tahunnya. Jadi keterlibatan BAPPEDA sesuai dengan tugas pokok dan
fungsinya dalam hal penyelarasan perencanaan Desa dan Kabupaten"
(Wawancara, 4 oktober 2017).

Sementara itu berdasarkan hasil wawancara dengan Dinas Pemberdayaan Masyarakat dan Pemerintahan Desa yang diwakili oleh Sekretaris Dinas menjelaskan

"Dinas Pemberdayaan Masyarakat dan Pemerintahan Desa Kabupaten Konawe selaku Ketua Tim Sekretariat Kabupaten dalam Pengelolaan ADD. Fungsinya adalah : (1) melakukan fungsi administrasi umum tentang pelaksanaan $A D D_{\text {; (2) }}$ melakukan verifikasi proposal ADD; (3) memproses rekomendasi pencairan $A D D$; (4) melakukan monitoring, evaluasi serta pengawasan atau pelaksanaan ADD; dan (5) 
melaporkan kepada Tim Fasilitasi Kabupaten melalui inspektorat Kabupaten Konawe atau adanya indikasi penyalahgunaan dana ADD. Sekretaris DPMPD sebagai pemimpin kelompok kerja (Pokja) sekretariat untuk melaksanakan sebagian tugas-tugas Tim Fasilitasi Tingkat Kabupaten dalam menangani ADD" (Wawancara, 4 Oktober 2017)

Mengenai peran dan tugas Badan Pengelola Keuangan dan Aset Daerah dalam ADD diungkap oleh Kepala Seksi Perbendaharaan Kabupaten Konawe melalui wawancara sebagai berikut :

"Pengelolaan ADD tahun 2017, Peran BPKAD dalam Tim Fasilitasi Kabupaten adalah melakukan verifikasi dan pencairan dana setelah mendapat persetujuan dari DPMPD. Desa yang diberikan rekomendasi oleh DPMPD untuk pencairan dana di BPKAD harus melampirkan : (I). Laporan pertanggungjawaban penggunaan ADD tahun sebelumnya; (2). Laporan penggunaan ADD tahun sebelumnya yang diverifikasi oleh Tim Fasilitasi Kecamatan; (3) Berita Acara Pemeriksaan Kas; (4). Laporan Realisasi penggunaan ADD tahun sebelumnya; (5). Hasil verifikasi Tim Fasilitasi Kecamatan; (6). Laporan realisasi penggunaan APBDes tahun sebelumnya; (7). Bukti setoran PPN/PPh tahun sebelumnya; (8). Peraturan Desa tentang RPJMDesa; (9). Laporan Penyelenggaraan Pemerintahan Desa (LPPD) tahun sebelumnya; (10). SK tentang Penetapan Kelompok UEP; (11). SK tentang Penetapan Bedah Rumah; (12). SK tentang Penetapan Tenaga Perawat Desa; (13). Berita Acara Musyawarah Desa tentang Penggunaan ADD tahun 2017; (14). RAB penggunaan ADD tahun 2017; (15) Perdes tentang APBDes untuk tahun anggaran 2017; (16). Foto fisik 0\%; (17). Foto copy rekening bendahara kegiatan ADD; (18). Foto copy Bendahara ADD; (19). Foto copy SK Kades yang diterbitkan oleh Bupati; (20). Foto copy SK Perangkat Desa yang diterbitkan oleh Kades; (21) SK pengangkatan RT, Puutobu, Imam Desa, Guru TPQ, Mangku dan Biksu; (22). Foto copy SK LPM Desa yang diterbitkan Kades; (23). Foto copy SK Tim PKK Desa yang diterbitkan oleh Kades; (24). Foto copy SK BPD yang diterbitkan oleh Bupati Konawe; (25). Foto copy SK pengurus Karang Taruna yang dikeluarkan oleh Kades; (26). Surat Pernyataan Tanggungjawab Mutlak terhadap penggunaan Anggaran ADD tahap I bermetarai (Wawancara, 6 Oktober 2017)

Penggunaan Alokasi Dana Desa di Kabupaten Konawe setiap tahunnya berbeda. Tahun 2014 Belanja ADD untuk Belanja Kegiatan Pemberdayaan Masyarakat Desa, yaitu untuk membiayai kegiatan yang bersifat pembangunan sarana dan prasarana (belanja barang dan belanja modal) serta belanja Peningkatan Kinerja Aparatur di Desa. Belanja Kegiatan Penyelenggaraan Pemeintahan Desa diprioritaskan untuk belanja Aparatur dan Belanja Operasional Desa. Belanja Aparatur Desa adalah Tunjangan Penghasilan Aparat Pemerintah Desa (TPAPD) bagi Kepala Desa dan Perangkatnya yang besarannya ditetapkan dengan Keputusan Bupati. Belanja Operasional Desa yaitu untuk membiayai kegiatan penunjang operasional tim pelaksana Desa dan Belanja Penguatan Kelembagaan Pemerintah Desa dan Lembaga Kemasyarakatan Desa.

Terkait penggunaan ADD tersebut setiap tahunnya berdasarkan petunjuk yang terdapat pada Peraturan Bupati Konawe setiap tahunnya. Hal ini dapat dilihat dari pernyataan yang disampaikan oleh beberapa Kepala Desa berikut ini : 
"Kades Amokuni, Tahun 2014 kegiatan pembedayaan masyarakat diperuntukkan untuk belanja modal dan peningkatan kapasitas kinerja aparatur pemerintah desa melalui bimbingan teknis. Belanja Modal dilakukan untuk pembelanjaan komputer, meja biro, lemari arsip, kursi dan penyambungan KWH dengan total nilai Rp. 4.024.000,- (empat juta dua puluh empat ribu rupiah). Kegiatan bimbingan teknis terdiri dari biaya kontribusi peserta Rp. 4.000.000,- (empat juta rupiah), biaya tiket pesawat (transportasi) sebesar Rp. 3.000.000,- (tiga juta rupiah) dan uang saku peserta bimtek sebesar Rp. 2.000.000,- (dua juta rupiah). Sehingga total dana pemberdayaan untuk tahun 2014 sebesar Rp. 13.024.000,- (tiga belas juta dua puluh empat ribu rupiah) (Wawancara, 7 Oktober 2017)

Pernyataan tersebut didukung oleh Kades Morosi di Kecamatan Morosi, Kades Galu di Kecamatan Anggalomoare dan Kades Hongoa di Kecamatan Pondidaha bahwa kegiatan pemberdayaan tahun 2014, 2015, 2016 dan 2017 dilaksanakan berdasarkan Peraturan Bupati Konawe. Kami para Kepala Desa tidak bisa menympang dari ketentuan Peraturan Bupati Konawe (wawancara, 8 Oktober 2017)

Peran dan fungsi Camat dalam Pengelolaan ADD setiap tahun sesuai dengan Peraturan Bupati Konawe. Untuk kegiatan pengelolaan ADD tahun 2017 sebagaimana diungkap oleh Camat Sampara berikut ini : "Tim faslitasi Kecamatan terdiri dari unsur perangkat Kecamatan yang memnfasilitasi pelaksanaan ADD yang dutetapkan dengan Keputusan Camat dengan susunan sebagai berikut : (1). Camat sebagai Ketua Tim; (2). Kasi P3MD sebagai sekretaris dan (3) Kasi Pemerintahan dan Kasi Kesra sebagai anggota. Tugas Tim Fasilitasi Tingkat Kecamatan adalah sebagai berikut : (1). Mengkoordinasikan pelaksanaan musyawarah perencanaan pembangunan desa dalam wilayah kecamatan; (2). Membantu PTPKD menyusun rencana teknis penggunaan ADD kelengkapannya; (3) merekomendasikan usulan pencairan ADD dari Desa yang telah memenuhi persyaratan; (4). Menfasilitasi upaya pemecahan masalah dalam pelaksanaan ADD; (5). Menfasilitasi PTPKD dalam menyusun laporan pertanggunjawaban ADD; (6). Melakukan pemantauan /pengendalian terhadap proses terhadap kegiatan di Desa yang pembiayaannya bersumber dari ADD. Pernyataan Camat Sampara tersebut dibenarkan oleh Camat Onembute, Konawe, Uepai dan Wawotobi".

Tahun 2015, penggunaan ADD dibagi atas 2 (dua), yaitu : (l) untuk penyelenggaraan Pemerintahan Desa; dan (2) untuk Pemberdayaan Masyarakat. Belanja Kegiatan Penyelenggaraan Pemerintahan Desa diprioritaskan untuk Belanja Aparatur dan Belanja Operasional Desa. Belanja Pemberdayaan Masyarakat sebesar Rp. 9.000.000,- (Sembilan juta) pertahun. ADD untuk pemberdayaan masyarakat penggunaannya meliputi belanja pembangunan sarana dan prasarana di dalam skala kecil (berdasarkan skala prioritas hasil musrembang tingkat Desa, meliputi : (a) perpustakaan Desa (pengadaan bahan buku bacaan), (b) computer (bukan laptop), (c) pemasangan KWH listrik; (d) pengadaan meubeler (kursi, meja ketja biro dan lemarai arsip, dan (e) belanja pembangunan (fisik).

Selanjutnya pada tahun 2016 arah penggunaan ADD terbagi menjadi 3 (tiga) bagian, yaitu : (l) untuk penyelenggaraan pemerintahan Desa; (2) ADD untuk pembangunan; dan (3) ADD untuk pemberdayaan masyarakat. Belanja kegiatan penyelenggaraan Pemerintahan Desa diprioritaskan untuk Belanja Pengahasilan Tetap Kepala Desa, Tunjangan Perangkat Desa dan Belanja Operasional Pemerintah Desa. Sementara itu ADD untuk belanja pembangunan, pemberdayaan masyarakat dibagi menjadi 2 (dua) kategori, yaitu : (l) Desa yang tidak mendapatkan Dana Desa (DD) dari APBN tahun 2016 (Desa Non APBD) sebesar Rp 13.000.000,- (tiga belas juta rupiah) pertahun dan ADD belanja pembangunan dan pemberdayaan masyarakat bagi desa yang mendapatkan Dana Desa (DD) yang bersumber dari APBN tahun 2016 (Desa Penerima Dana Desa) sebesar Rp. 3.500.000,- (tiga juta lima ratus ribu rupiah) pertahun. Selain dua kategori desa tersebut pada tahun 2016 
terdapat pula kebijakan ADD untuk Kampung PERISAI (Pembangunan Masyarakat Sejahtera dan Mandiri). Pada Desa Perisasi tersebut diberikan Dana ADD sebesar Rp. 150.000.000,- (seratus lima puluh juta rupiah) pertahun. ADD bagi Kampung Perisai dipergunakan untuk belanja pembangunan infrastruktur yang bersufat prioritas dengan berdasarkan potensi Desa masing-masing. Pembangunan Kampung Perisai diprioritaskan untuk membiayai kegiatan Bedah Rumah. Selain kegiatan Bedah Rumah tersebut penggunaan ADD dapat digunakan untuk kegiatan lain yang prioritas berdasarkan kebutuhan masyarakat, antara lain : (1). Pembangunan rehabilitasi sarana dan prasarana jalan /jembatan, penyediaan sarana dan prasarana air bersih melalui sistem perpipaan (gavitasi), sumur bor dan sumur gali; (2). Pembangunan / rehabilitasi jaringan irigasi; (3). Pembangunan / rehabiltasi jalan usaha tani; (4). Pembangunan/rehabilitasi rumah ibadah.

Tahun 2017 besaran ADD di Kabupaten Konawe terbagi menjadi 4 (empat), kategori, yaitu: (1). Kelompok A masing-masing sebesar Rp. 191.108.590,- (seratus sembilan puluh satu juta seratus delapan ribu lima ratus sembilan puluh rupiah); (2). Kelompok B masing-masing sebesar Rp 194.108.590,- (seratus sembilan puluh empat juta seratus delapan ribu lima ratus sembilan puluh rupiah); (3). Kelompok C masing-masing sebesar Rp 197.108.590,- (seratus sembilan puluh tujuh juta seratus delapan ribu lima ratus sembilan puluh rupiah); (4). Kelompok D sebesar Rp. 200.108.590,- (dua ratus juta seratus delapan ribu lima ratus sembilan puluh rupiah);

Pengalokasian ADD tahun 2017 didasarkan atas Petugas Keagamaan. Kelompok A pada point 1 adalah kelompok Desa yang petugas keagamaannya terdiri dari Imam Desa. Kelompok B pada poin 2, petugas keagamaannya terdiri dari Imam Desa, Mangku atau Pendeta; Kelompok C poin 3 terdiri dari Imam Desa, Mangku dan Pendeta; dan Kelompok D poin 4 petugas keagamaannya terdiri atas Imam Desa, Mangku dan Pendeta dan Biksu.

Arah penggunaan ADD tahun 2017 dibagi atas 4 (empat) bidang belanja, yaitu : (1). Belanja Bidang Penyelenggaraan Pemerintahan Desa; (2). Belanja Bidang Pelaksanaan Pembangunan; (3). Belanja Bidang Pelaksanaan Kemasyarakatan; dan (4). Belanja Bidang Pemberdayaan Masyarakat. Belanja bidang kegiatan penyelenggaraan Pemerintahan Desa diprioritaskan untuk penghasilan tetap Kepala Desa dan Perangkat Desa, Operasional Kegiatan Pemerintah Desa, Operasional BPD, tunjangan BPD dan Operasional RT. Belanja ADD untuk bidang pembangunan Desa diprioritaskan untuk Bantuan Perumahan Swadaya Masyarakat (Perisai), melaljui kegiatan bedah rumah dengan memberikan bantuan sebesar Rp. 5.000.000,- (lima juta rupiah) untuk setiap rumah. Belanja ADD untuk kegiatan pembinaan kemasyarakatan diprioritaskan untuk operasional PKK, oeparsional LPM, operasional Karang Taruna, Insentif Tenaga Keperawatan Desa, Insentif Puutobu, Insentif Imam Desa, Insentif Guru TPQ, Insentif Pendeta, Insentif Mangku, Insentif Biksu dan Operasional Perawat Desa.. sedangkan untuk kegiatan bidang pemberdayaan masyarakat diprioritaskan untuk membiayai kegiatan Ekonomi Masyarakat berupa dukungan bantuan permodalan terhadap Usaha Ekonomi Produktif dan penguatan Kapasitas Perawat Desa. Belanja Bidang Pemberdayaan Masyarakat ditetapkan sebesar Rp. 13.000.000,- (tiga belas juta rupiah) setiap desa dan dipergunakan untuk Rp. 10.000.000,- (sepuluh juta rupiah) untuk bantuan UEP dan Rp. 3.000.000,- (tiga juta rupiah) untuk peningkatan kapasitas perawat Desa.

Penggunaan ADD untuk pemberdayaan dan pembangunan tahun 2016 dan 2017 di Desa Baruga Kecamatan Uepai dan Desa Asao kecamatan Tongauna dalam hasil wawancara bersama Kepala Desa masing-masing sebagai berikut : "ADD untuk belanja pemberdayaan di Desa Baruga Kecamatan uepai tahun 2016 sebesar Rp. 13.000.000,- (tiga belas juta rupiah) untuk kegiatan rehabiitasi balai pertemuan, pengadaan mebuler dan sarana kantor desa lainnya. Sementara tahun 2017 belanja pemberdayaan dan pembangunan masing-masing sebesar Rp. 13.000.000,- (tiga belas juta rupiah) dan Rp. 35.000.000,- (tiga puluh lima juta rupiah). ADD tersebut digunakan untuk rehabilitasi rumah tidak layak huni dengan pengadaan sengnisasi atau lantainisasi untuk 7 unit rumah. Sedangkan kegiatan pemberdayaan digunakan untuk kegiatan Usaha Ekonomi Produktif (UEP) sebanyak 10 kelompok. 1 kelompok mendapakan alokasi dana sebesar Rp. 1.000.000,- (satu juta rupiah). 
Sedangkan sisanya Rp. 3.000.000,- (tiga juta rupiah) digunakan untuk operasional dan peningkatan kapasitas Perawat Desa. Hal senada juga disampaikan oleh Kepala Desa Asao bahwa untuk kegiatan ADD bidang pemberdayaan dan pembangunan tahun anggaran 2016 di Desa Asao dipergunakan untuk membiayai kegiatan fisik berupa rehab kantor desa. sedangkan tahun 2017 adalah kegiatan sengnisasi untuk 7 unit rumah dan UEP serta operasional dan peningkatan kapasitas perawat desa".

Sementara itu Menurut Kepala Desa Saponda Laut Kecamatan Soropia, Desa Lamelay Kecamatan Meluhu, Desa Anggoro Kecamatan Abuki dan Desa Mataiwoi Kecamatan Amonggedo Kegiatan ADD untuk pembangunan dan pemberdayaan tahun 2016 adalah kegiatan Beda Rumah dengan anggaran Rp. 150.000 .000 (seratus lima puluh juta rupiah). Empat desa tersebut merupakan program khusus Pemerintah Kabupaten Konawe melalui kebijakan Kampung Perisai (Pembangunan Masyarakat Sejahtera dan Mandiri). Program ini dikucurkan 1 (satu) Desa setiap Kecamatan. Sedangkan menurut Kepala Desa Porara Kecamatan Morosi, Desa Lamokuni Kecamatan Wonggeduku Barat kegiatan ADD untuk pembangunan dan pemberdayaan digunakan untuk pembangunan jalan usaha tani dan pengadaan deuker. Sementara itu penggunaan ADD untuk bidang pembangunan dan pemberdayaan pada tahun 2017 hampir di semua desa lokasi sasaran penelitian ini memprogramkan hal yang sama yaitu Sengnisasi untuk 7 unit rumah setiap Desa, UEP dan operasional dan peningkatan kapasitas perawat Desa.

Berdasarkan uraian tersebut di atas dapat dapat disimpulkan bahwa pelaksanaan ADD dalam bidang pembangunan dan pemberdayaan di Kabupaten Konawe selalu mengacu pada regulasi yang ada. Pelaksanaan ADD sudah diatur dalam peraturan Bupati yang diterbitkan setiap tahunnya. Tim Pelaksana Pengelola Keuangan Desa dalam melaksanakan kegiatannya selalu mengacu kepada Peraturan Bupati tersebut, sehingga tidak ada satu kegiatan pun yang dilaksanakan bertentangan dengan Peraturan Bupati yang ada. "Pelaksanaan ADD untuk bidang pembangunan dan pemberdayaan secara umum di lokasi penelitian sangat bermanfaat bagi pemerintah Desa dan masyarakat. Kegiatan ADD untuk pemberdayaan sejak tahun 2014 dan 2015 diarahkan untuk sarana dan prasarana penyelenggaraan pemerintah desa. Hal ini dilakukan dalam rangka mendorong dan meningkatkan kualitas sarana pemerintahan Desa dalam upaya perbaikan dan peningkatan kualitas pelayanan kepada masyarakat"

Adapun beberapa harapan masyarakat dan pemerintah Desa terkait implementasi ADD tersebut adalah agar alokasi anggaran untuk ADD dalam bidang pemberdayaan dan pembangunan Desa untuk ditingkatkan pada tahun-tahun berikutnya. Selain itu dana ADD juga diharapkan dapat digunakan untuk membiayai kebutuhan masyarakat yang lebih luas. Selain itu pendanaan ADD untuk pemberdayaan dan pembangunan didasarkan atas kebutuhan rill masyarakat desa dan direncanakan bersama melalui musyawarah desa. Pencairan ADD diharapkan tepat waktu sehingga realisasi pelaksanaan kegiatan ADD tersebut tepat waktu.

Dalam proses perencanaan ADD dan pelaksanaan serta pengawasan dilakukan secara kolektif bersama masyarakat, Pemerintah Desa, BPD yang disepakati dengan membentuk Tim. Tim Perencanaan Pembangunan Desa mempunyai tugas melakukan fasilitasi perencanaan mulai dari tingkat RT, Dusun sampai dengan tingkat Desa. Pada tingkat Desa tim perencana tersebut memaparkan rencana kegiatan yang telah dijaring pada RT dan Dusun, sehingga pada saat rapat di Desa dilakukan lokakarya untuk menjadi RPJM Desa dan RKP Desa. Membentuk Tim Pelaksanaan Kegiatan sesuai dengan ketentuan yang termuat dalam Peraturan Bupati. Pengawasan dilakukan oleh masyarakat bersama BPD.

Arah kebijakan ADD untuk bidang pembangunan dan pemberdayaan tahun 2017 sangat dirasakan manfaatnya bagi semua masyarakat Desa yang ada di Kabupaten Konawe. Pada tahun 2016 program beda rumah hanya diperuntukkan bagi masyarakat yang tergolong kategori Kampung Perisai. Sementara itu Desa Kampung Perisai pada tahun 2016 hanya satu Desa dalam satu Kecamatan. Oleh karena itu pada tahun 2016 terdapat 26 Desa yang masuk dalam kategori Kampung Perisai. Pada tahun 2017 program beda rumah semua dilaksanakan 
pada 27 wilayah Kecamatan dan 289 Desa. setiap desa mendapat ADD untuk pembangunan sebesar Rp. 35.000.000 (tiga puluh lima juta rupiah). Setiap Desa berkewajiban untuk melakukan beda rumah sebanyak 7 (tujuh) unit dengan alokasi anggaran sebesar Rp. 5.000.000,- (lima juta rupiah) perunit. Semntara untuk kegiatan pemberdayaan dilakukan dalam rangka pengembangan Usaha Ekonomi Produktif. Setiap kelompok diberi bantuan stimulan sebesar Rp. 1.000.000,- (satu juta rupiah) perkelompok dan maksimal sebanyak 10 (sepuluh) kelompok. Sehingga bantuan UEP sebesar Rp. 10.000 .000 (sepuluh juta rupiah) perdesa. Sisanya Rp. 3.000.000,- (tiga juta rupiah) untuk operasional dan penguatan kapasitas Bidan Desa. Oleh karena itu ADD untuk pemberdayaan masyarakat sangat dirasakan sekali manfaatnya bagi warga masyarakat.

\section{PERKEMBANGAN ALOKASI ANGGARAN ADD KABUPATEN KONAWE SELAMA 4 TAHUN}

\section{(1). Anggaran ADD Kabupaten Konawe Tahun 2014}

Anggaran ADD Kabupaten Konawe Tahun 2014 sebesar Rp 22.017.520.000,- (dua puluh dua miliayar tujuh belas juta lima ratus dua puluh ribu rupiah). Dana tersebut diperuntukkan 280 Desa. Selanjutnya mengenai distribusi ADD Kabupaten Konawe Tahun Anggaran 2014 dapat dilihat gambar 1 berikut :

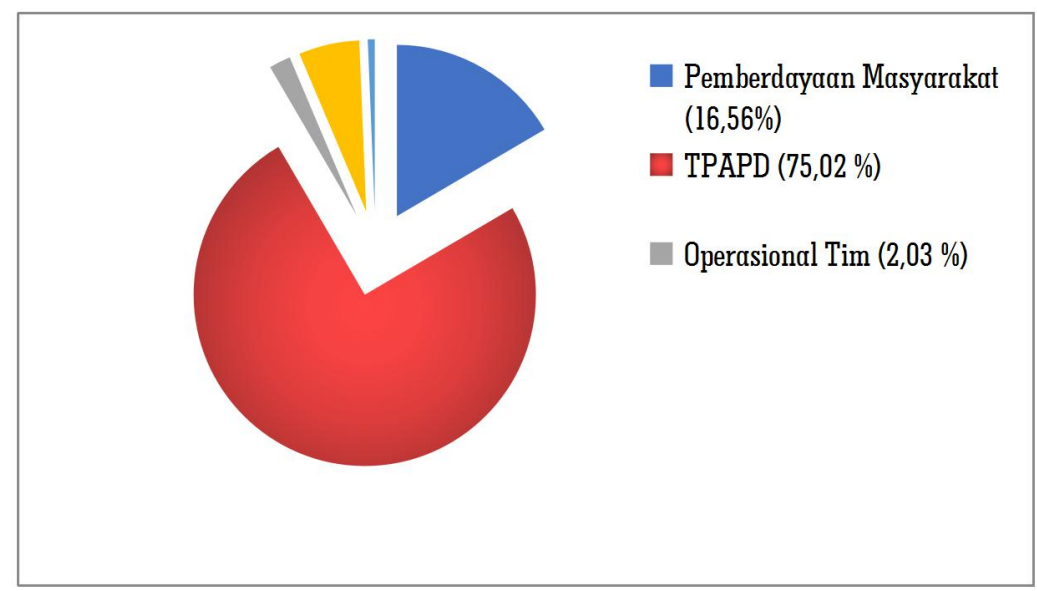

Gambar 1. Distribusi ADD Kabupaten Konawe Tahun Anggaran 2014

Berdasarkan gambar 1 di atas menunjukkan bahwa porsi ADD untuk pemberdayaan masyarakat pada tahun 2014 sebesar Rp. 3.640.720.000,- (tiga miliyar enam ratus empat puluh juta tujuh ratus dua puluh ribu rupiah) atau 16,56\%. Tunjangan Penghasilan Aparat Pemerintah Desa (TPAPD) sebesar Rp. 16.518.600.000 (enam belas milyar lima ratus delapan belas juta enam ratus ribu rupiah) atau 75,02\%. Operasional Tim Pelaksana Desa sebesar Rp. 448.000.000 (empat ratus empat puluh delapan juta rupiah atau 2,03\%. Kelembagaan Desa sebesar Rp.1.260.000.000,- (satu milayar dua ratus enam puluh juta rupiah) atau 5,72\% dan belanja ATK sebesar Rp. 144.200.000,- (seratus empat puluh empat juta dua ratus ribu rupiah) atau 0,65\%.

\section{(2). Anggaran ADD Kabupaten Konawe Tahun 2015 untuk Desa APBN}

Anggaran ADD Kabupaten Konawe Tahun 2016 untuk Desa APBN sebesar Rp 22.017.476.000,- (Dua puluh dua miliayar tujuh belas juta empat ratus tujuh puluh enam ribu rupiah). Dana tersebut diperuntukkan 283 Desa. Porsi ADD untuk pemberdayaan masyarakat sebesar 2.484.000.000,- (dua milyar empat ratus delapan puluh empat juta rupiah) atau 11,50\%. Tunjangan Penghasilan Aparat Pemerintah Desa (TPAPD) sebesar Rp. 17.099.400.000,- (tujuh belas milyar sembilan puluh sembilan juta empat ratus ribu rupiah) atau 79,98\%. Operasional Tim Pelaksana Desa sebesar Rp. 440.000.000,- (empat ratus empat puluh juta rupiah) atau 2,06\%. Kelembagaan Desa sebesar Rp.1.237.500.000,- (satu milayar dua ratus tiga puluh juta lima ratus rupiah) atau 5,79\% dan belanja ATK sebesar Rp. 130.328.000,- (seratus tiga puluh juta tiga ratus dua puluh delapan ribu 
rupiah) atau 0,61\%. Selanjutnya mengenai distribusi ADD Kabupaten Konawe Tahun Anggaran 2015 dapat dilihat gambar 2 berikut :

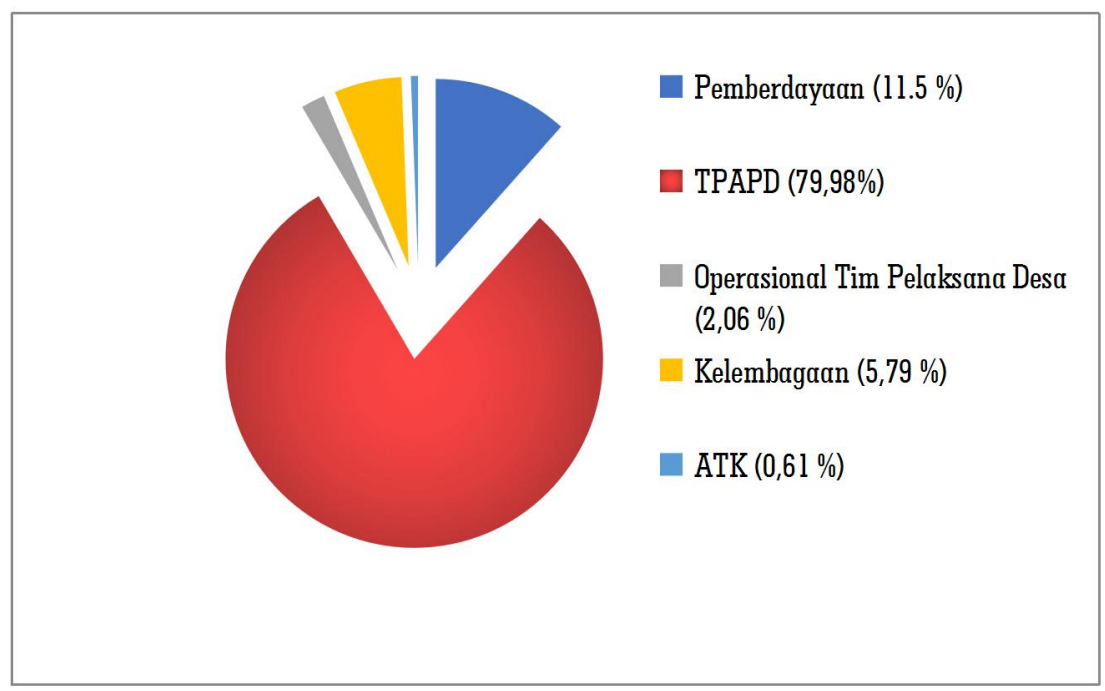

Gambar 2. Distribusi ADD Kabupaten Konawe Tahun Anggaran 2015

\section{(3). Anggaran ADD Kabupaten Konawe Tahun 2016}

Anggaran ADD Kabupaten Konawe Tahun 2016 dibagi menjadi 3 (tiga) kategori. Kategori pertama, yaitu Desa yang mendapatkan Alokasi Dana Desa yang telah mendapat Dana Desa yang bersumber dari APBN. Desa ini berjumlah 220 Desa. Porsi anggaran Desa APBN ini sebesar Rp. 19.616.740.000 (sembilan belas miliar enam ratus enam belas juta tujuh ratus empat puluh ribu rupiah) atau 4,58\%. Sementara porsi ADD untuk SILTAP Kepala Desa dan Perangkat Desa sebesar Rp. 16.795.800.000,- (enam belas miliyar tujuh ratus sembilan puluh lima juta delapan ratus ribu rupiah) atau 86,20\%. Operasional pemerintah desa sebesar Rp. 817.439 .000 (delapan ratus tujuh belas juta empat ratus tiga puluh sembilan ribu rupiah) atau 4,05\%. Sedangkan operasional lembaga desa sebesar Rp. 976.500.000,- (sembilan ratus tujuh puluh enam juta lima ratus ribu rupiah) atau 5,12\%. Selanjutnya dapat dilihat pada gambar 3 berikut:

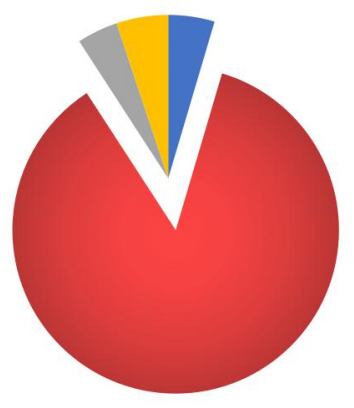

Pembangunan \& Pemberdayaan Masyarakat (4,58\%)

Siltap $(86,20 \%)$

Operasional Pemerintah Desa (4,05\%)

Kelembagaan Masyarakat (5,12 \%)

Gambar 3. Anggaran ADD Kabupaten Konawe Tahun 2016 
Anggaran ADD kategori kedua adalah ADD bagi Desa yang tidak mendapatkan Dana Desa dari APBN. Desa ini berjumlah 46 Desa yang tersebar dalam 16 Kecamatan. Distribusi ADD untuk Kategori Desa Non APBN dapat dilihat pada gambar 4 berikut :

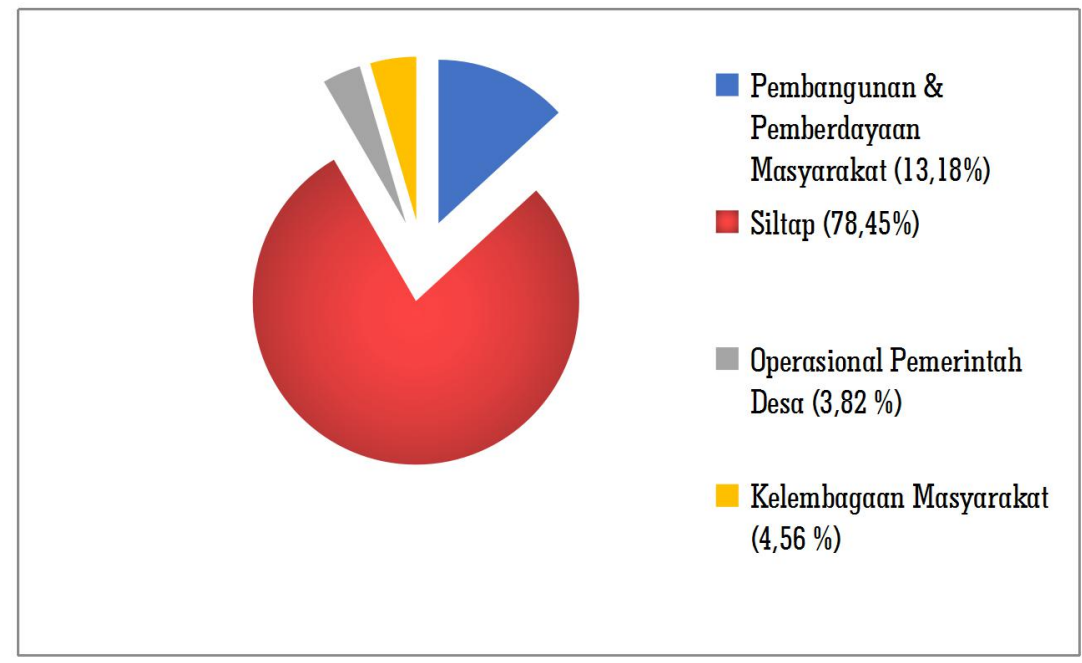

Gambar 4. Distribusi ADD untuk Kategori Desa Non APBN

Berdasarkan gambar 4 nampak jelas bahwa porsi ADD untuk pemberdayaan masyarakat sebesar 13,18\%, Siltap Kepala Desa dan Perangkat Desa sebesar 78,45\%, Operasional Pemerintah Desa sebesar 3,28\% dan Kelembagaan masyarakat sebesar $4,56 \%$.

Anggaran ADD untuk kategori ketiga adalah Desa yang menerima ADD kategori Kampung Perisai. Desa yang mendapat ADD kategori ketiga ini sebanyak 26 Desa yang tersebar dalam 26 Kecamatan yang ada di Kabupaten Konawe. Distribusi ADD bagi Desa Kampung Perisai Tahun Anggaran 2016 dapat dilihat pada gambar 5 berikut ini :

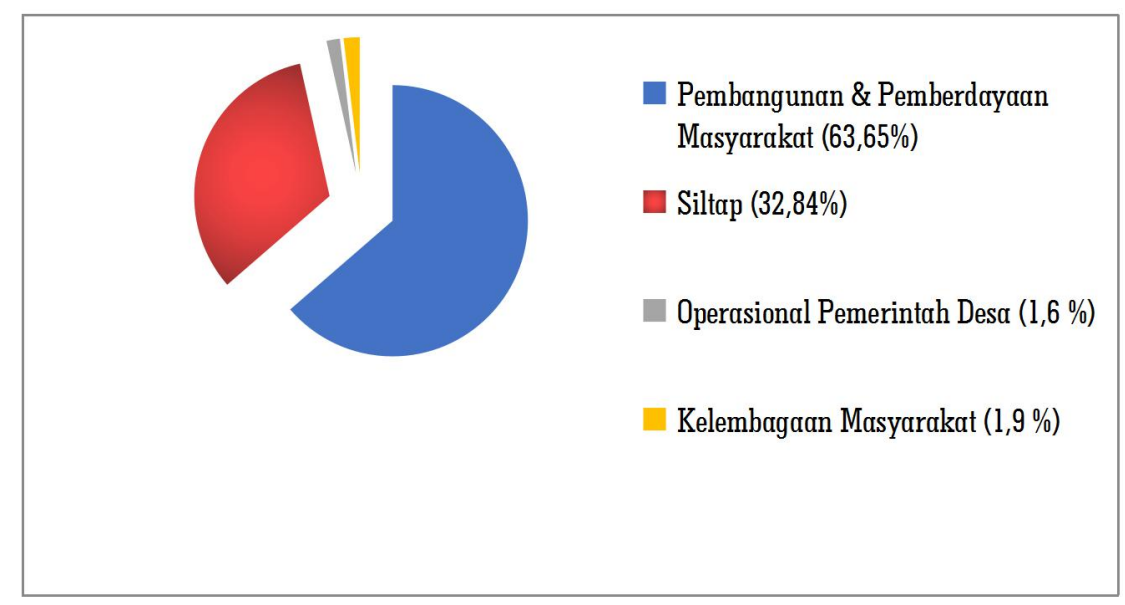

Gambar 5. Distribusi ADD bagi Desa Kampung Perisai Tahun Anggaran 2016

Berdasarkan gambar 5 nampak jelas terlihat bahwa distribusi ADD kategori Desa Kampung Perisai di Kabupaten Konawe Tahun 2016, porsi ADD untuk kegiatan pembangunan dan pemberdayaan sebesar 63,65\%, SILTAP Kepala Desa dan Perangkat Desa sebesar 32,84\%, Operasional Pemerintah Desa sebesar 1,16\% dan Kelembagaan Masyarakat Desa sebesar 1,9\%.

\section{(4). Anggaran ADD Tahun Anggaran 2017 di Kabupaten Konawe}


Porsi ADD Kabupaten Konawe tahun 2017 sebesar Rp. 56.655.142.640.000 (lima puluh enam miliyar enam ratus lima puluh lima juta seratus empat puluh dua juta enam ratus empat puluh ribu rupiah). Selanjutnya distribusi ADD di Kabupaten Konawe Tahun Anggaran 2017 dapat dilihat gambar 6 berikut :

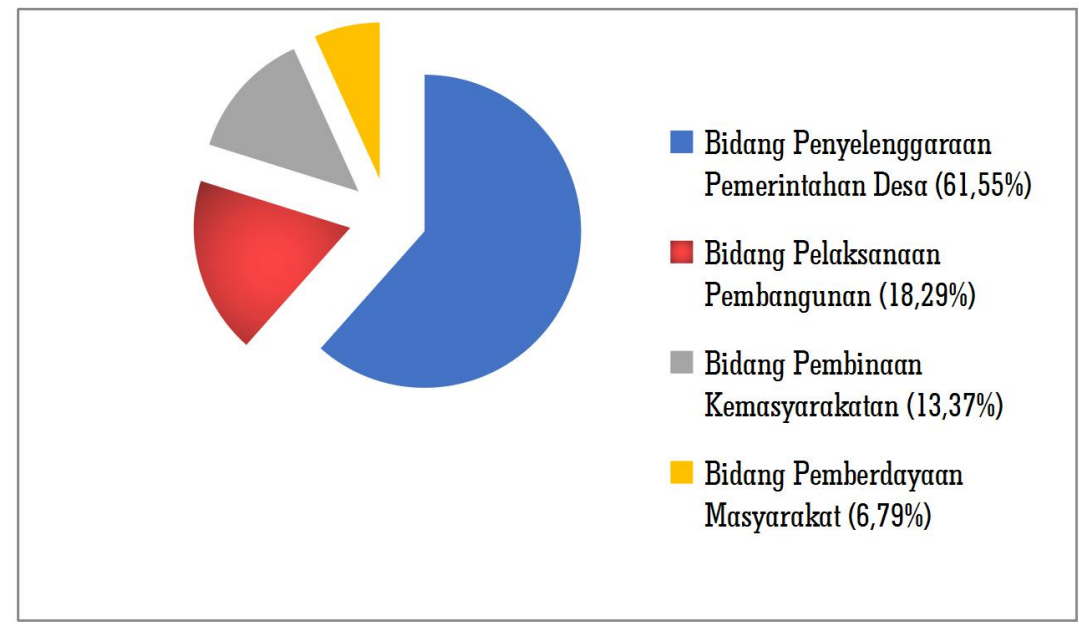

Gambar 6. Distribusi ADD di Kabupaten Konawe Tahun Anggaran 2017

Berdasarkan gambar 6 di atas nampak jelas bahwa terjadi peningkatan porsi ADD pada tahun 2017 seiring peningkatan jumlah Desa. Desa di Kabupaten Konawe pada tahun 2017 sebanyak 293 Desa. Porsi anggaran ADD untuk bidang penyelenggaraan Pemerintahan Desa sebesar 61,55\%. Sementara porsi ADD untuk bidang pelaksanaan pembangunan sebesar $18,29 \%$. Sedangkan porsi ADD untuk bidang pembinaan kemasyarakatan sebesar 13,37\% dan Bidang pemberdayaan masyarakat sebesar 6,79\%.

\section{PEMBAHASAN HASIL PENELITIAN}

Berdasarkan hasil kajian yang dilakukan terhadap pelaksanaan ADD selama 4 (empat) tahun terakhir menunjukan, bahwa nilai ADD untuk setiap tahunnya berfluktuasi. Pada tahun 2014 porsi Anggaran ADD mencapai Rp. 22.017.520.000,- sementara untuk pemberdayaan mencapai 3,646.720.000 atau 16,56\% dari total ADD Kabupaten Konawe. Dana tersebut diperuntukkan 280 Desa. setiap Desa mendapatkan porsi ADD untuk Kegiatan pemberdayaan sebesar Rp. 13.024.000,-. ADD tersebut digunakan untuk belanja modal pengadaan sarana dan prasarana penunjang kinerja pemerintah desa seperti pengadaan mobiler (meja biro, kursi, lemari arsip), komputer dan pengadaan KWH listrik di Kantor Desa dan Kegiatan bimbingan teknis peningkatan kapasitas aparatur Pemerintah Desa. ADD memberikan kontribusi yang sangat berarti karena selama ini sarana dan prasarana kantor desa yang menunjang pelaksanaan kinerja Pemerintah Desa sangat terbatas. Melalui porsi anggaran ADD tersebut kinerja pemerintah Desa secara perlahan-lahan diperbaiki. Kinerja tersebut berpengaruh dengan pelayanan kepada masyarakat. Sebelumnya pelayanan dilakukan di rumah Kepala Desa tetapi dengan adanya sarana kantor pelayanan dilakukan di Kantor Desa. Harapan masyarakat dengan ADD tersebut agar pada tahun selanjutnya porsi ADD lebih ditingkatkan lagi dalam aspek yang lebih luas ke masyarakat, sehingga dapat memicu partisipasi masyarakat untuk ikut serta dalam pelaksanaan pembangunan. Keterlibatan masyarakat dalam perencanaan secara perlahan-lahan dapat ditingkatkan sehingga rasa kepemilikan terhadap apa yang direncanakan oleh masyarakat dan pemerintah Desa dalam bentuk pembangunan dapat dipelihara dan dilestarikan dengan berdasarkan karakteristik dan nilai-nilai budaya masyarakat setempat. Porsi Anggaran terbesar yang mendapat ADD pemberdayaan tahun 2014 adalah Kecamatan Wonggeduku sebesar 1,66\% dan Kecamatan terrendah yang memperoleh ADD adalah Kecamatan Routa, Assinua, Meluhu, Wawotobi dan Konawe sebesar 0,41\%. Besaran porsi ADD tersebut didasarkan jumlah 
Desa yang ada di wilayah Kecamatan tersebut. Semakin banyak jumlah Desa yang ada di wilayah kecamatan semakin besar porsi ADD yang masuk di wilayah tersebut.

Tahun 2015 porsi ADD hampir sama dengan ADD tahun 2014 dengan nilai sebesar Rp. 22.017.476.000,-. Nilai ADD untuk bidang pemberdayaan mengalami penurunan sangat tajam sebesar Rp. 2.484.000.000,-. Penurunan nilai ADD untuk bidang pemberdayaan ini disebabkan oleh karena tidak bertambahnya anggaran ADD pada tahun 2015, sementara jumlah desa bertambah menjadi 283 Desa. Kondisi ini mempengaruhi porsi ADD dalam setiap bidangnya, sehingga salah satu alternatif yang dilakukan oleh Pemerintah Kabupaten Konawe adalah mengurangi porsi anggaran untuk bidang pemberdayaan.

Menurunnya porsi anggaran pemberdayaan tersebut tidak mempengaruhi kinerja Pemerintah Desa maupun masyarakat Desa. Porsi ADD untuk pemberdayaan masyarakat tahun 2015 sebesar Rp. 9.000.000,-. Dana tersebut diperuntukkan untuk belanja pengadaan sarana dan prasarana kantor desa seperti pengadaan mebuler, KWH lisrik, komputer dan belanja pendukung pelaksanaan kegiatan pemerintah Desa dalam fasilitasi kegiatan melalui rapat, musrembang dan kegiatan lainnya. Selama kurung waktu dua tahun pelaksanaan kegiatan pemberdayaan masyarakat diarahkan untuk belanja pengadaan sarana dan prasarana dasar penunjang pelaksanaan kegiatan Pemerintah Desa dalam skala kecil. Nilai ADD untuk pemberdayaan pada tahun 2015 hanya mencapai $11,50 \%$ atau mengalami penurunan sebesar $4,94 \%$ dari $16,56 \%$ pada tahun 2014 . Kecamatan Uepai mendapat porsi terbesar yaitu sebesar 1,66\% dari total ADD tahun 2015 dan Kecamatan Meluhu dan Bondola merupakan kecamatan terkecil yang mendapat porsi ADD.

Pada tahun 2016 porsi anggaran pemberdayaan dan pembangunan desa mengalami peningkatan dibandingkan dengan tahun 2014 dan 2015. Porsi ADD tahun 2016 secara keseluruhan mencapai 29.988.763.000,- Anggaran tersebut diklasifikasi menjadi 3 (tiga) kategori, yaitu : (1) Kategori Desa penerima dana APBN; (2) Kategori Desa bukan penerima Dana APBN; dan (3) Kategori Desa Kampung Perisai. Demikian pula dengan porsi ADD untuk pembangunan dan pemberdayaan masyarakat juga terdapat 3 (tiga) kategori. Kategori pertama Desa yang mendapat Dana APBN sebanyak 220 Desa. setiap Desa mendapat alokasi dana pembangunan dan pemberdayaan sebesar Rp. 3.500.000,- dari total ADD pemberdayaan Desa APBN yaitu 759.500.000 atau 4,58\% dari total ADD Desa APBN. ADD pembangunan dan pemberdayaan tersebut setiap Desa dipergunakan untuk belanja penunjang kinerja Pemerintah Desa dalam rangka fasilitasi kegiatan pemerintah desa seperti rapatrapat, musrembang dan kegiatan pemerintah Desa lainnya. Sementara kategori kedua desa yang tidak mendapat dana APBN sebanyak 46 Desa. setiap Desa memperoleh Dana ADD untuk pemberdayaan sebesar Rp. 13.000.000,- dari total anggaran sebesar Rp. 494.000 .000 atau 13,18\% dari total ADD untuk kategori desa non APBN. Kegiatan pemberdayaan bagi Desa Non APBN tersebut diarahkan untuk pelaksanaan pembangunan sarana dan prasarana dasar dalam skala kecil serta kebutuhan penunjang penyelenggaraan pemerintah Desa. Hal ini didukung oleh pernyataan hasil penelitian Rosalina (2013) mengunkapkan bawa kinerja pemerintah desa dalam pembengunan infrastruktur ialah mengedapankan aspirasi dan partisipasi masyarakat. Partisipasi merupakan keterlibatan secara terbuka (inclusion) dan keikutsertaan (involvemenet). Menurut Eko (2004) partisipasi dapat berupa voice (suara), akses dan kontrol. Untuk menggerakan pertisipasi masyarakat ditekankan pentingnya peran tokoh untuk menggerakan partisipasi masyarakat dalam perencanaan pembangunan sehingga menghasilkanperencanaan pembangunan yang efektif (Manolang, 2005). Partispasi masyarakat dalam penggunaan ADD sangat dibutuhkan dalam rangka menggerakan masyarakat untuk turut serta dalam pelaksanaan pembangunan serta membangkitkan modal sosial yang dapat mendukung pelaksanaan pembangunan.

Jika dilihat dari grafik statistik Kecamatan yang banyak menyerap ADD tertinggi bidang pembangunan dan pemberdayaan tahun 2016 untuk kategori Desa APBN adalah Kecamatan Wonggeduku Barat sebesar 0,42\% dari total ADD bidang pembangunan dan pemberdayaan masyarakat. Sementara Kecamatan Routa merupakan 
Kecamatan terrendah yang menyerap ADD bagi Desa APBN yaitu sebesar 0,05\%.. Kecamatan Wonggeduku Barat merupakan Kecamatan yang mempunyai Desa terbanyak di Kabupaten Konawe untuk kategori penerima ADD bagi Desa APBN. Sementara Kecamatan Routa merupakan kecamatan yang mempunyai jumlah Desa terkecil dari semua wilayah Kecamatan yang menerima ADD kategori Desa APBN.

Sementara itu jika dilihat dari statistik Desa penerima ADD dari Non APBN, Kecamatan terbesar yang menyerap dana ADD adalah Kecamatan Uepai sebesar 2,47\% dari total ADD bagi Desa penerima ADD kategori non APBN. Sementara yang terrendah adalah Kecamatan Kapoila, Bondoala dan Abuki sebesar 0,41\%.

Untuk kategori desa Kampung Perisai total ADD untuk pemberdayaan sebesar Rp. 150.000.000,- dari total anggaran ADD untuk Desa Kampung Perisai sebesar Rp. 3.600.000.000,- atau 63, 65\% untuk 26 Desa. porsi ADD untuk pemberdayaan sebanyak 26 Desa diarahkan untuk kegiatan beda rumah. Setiap unit rumah dialokasikan anggaran Rp. 15.000.000,- sehingga setia Desa melakukan kegiatan beda rumah sebanyak 10 unit. Ada juga Desa yang memprogramkan Jalan Usaha Tani dan perbaikan deuker seperti terjadi di Desa Lamokuni Kecamatan Wonggeduku Barat dan Porara di Kecamatan Morosi.

Masyarakat sangat merasakan manfaat terhadap program Desa Kampung Perisaii ini. Perencanaan dilakukan secara bersama-sama. Penentuan kebutuhan prioritas dalam setiap tahunnya selalu dilakukan atas hasil musyawarah, mulai musaywarah tingkat dusun sampai musyawarah tingkat Desa. ADD bidang pembangunan dan pemberdayaan dirasakan penting dan memberikan kontribusi yang sangat berarti bagi masyarakat miskin. Kontribusi ADD bidang pembangunan dan pemberdayaan dirasakan oleh masyarakat melalui program beda rumah ini. Selama tahun 2014, 2015 dan 2016 (bagi desa non APBN dan Desa APBN) kontribusi ADD bagi masyarakat sangat kecil sekali dampaknya. Hal ini disebabkan oleh karena ADD bidang pembangunan dan pemberdayaan hanya sampai pada Pemerintah Desa, walaupun dalam skala kecil hanya dapat digunakan untuk mendukung pelaksanaan kinerja aparatur pemerintah Desa dalam rangka perbaikan dan peningkatan pelayanan.

Partisipasi masyarakat bagi Desa Kampung Perisai sangat dominan. Partisipasi tersebut dilihat dari adanya kehadiran warga masyarakat dalam setiap kegiatan rapat-rapat di Desa. Kontribusi ADD sangat berkaitan dengan keikutsertaan masyarakat untuk berpartisipasi dalam pelaksanaan pembangunan Desa. untuk melibatkan partisipasi masyarakat, Pemerintah Desa harus dapat mengetahui kebutuhan masyarakat di Desanya. Masyarakat dapat berkontribusi kepada Pembangunan jika masyarakat tersebut merasa ada kontribusi yang diberikan kepada mereka. Oleh karena itu keberadaan program bedah rumah ini harus tetap dipertahankan dan diperluas dalam konteks yang lebih luas lagi sehingga dapat menyentuh kebutuhan warga masyarakat secara langsung. Dengan demikian secara sosial, politik, ekonomi dapat saling menunjang dan memberi kontribusi serta hubungan yang sinergitas antara Pemerintah dan masyarakat.

Tahun 2017 Anggaran ADD Kabupaten Konawe semakin meningkat jika dibandingkan dengan tahun sebelumnya. Pada tahun 2017 total ADD sebesar Rp. 56.655.142.640,- atau mengalami kenaikan sebesar 26.667.379.640,- atau 50\% total anggaran tahun sebelumnya yaitu 29.987.763.000. Peningkatan ADD tersebut disertai pula dengan peningkatan porsi anggaran masing-masing bidang. Bidang pembangunan Desa menyerap anggaran sebesar Rp. 10.360.000.000. sementara anggaran pemberdayaan mencapai Rp. 3.848.000.000,-. Porsi ADD setiap Desa untuk pelaksanaan pembangunan Desa sebesar Rp. 35.000.000,-Anggaran ini diperuntukkan kegiatan rehabilitasi perbaikan rumah untuk kegiatan Sengnisasi atau lantainisasi. Setiap Kepala Keluarga mendapatkan ADD sebesar Rp. 5.000.000,- untuk keperluan perbaikan rumah yaitu mengganti atap rumah dengan seng atau pengadaan lantainisasi rumah warga. Kebijakan ini berlaku untuk semua Desa di Kabupaten Konawe. Sementara itu anggaran ADD untuk pemberdayaan masyarakat dilakukan untuk pemberian bantuan stimulan bagi pedagang sayur-sayuran yang dikategorikan sebagai Kelompok Usaha Ekonomi Produktif (UEP).Setiap kelompok warga UEP tersebut mendapatkan ADD sebesar Rp. 1.000.000,- 
sebanyak 10 kelompok. Sedangkan sisanya Rp. 3.000.000,- digunakan untuk membiayai oprasional Bidan Desa dan Peningkatan Kapasitas Bidan Desa tersebut.

Berdasarkan sasaran dan arah kebijakan penggunaan ADD bidang pemberdayaan tersebut dirasakan sangat bermanfaat dan berkontribusi besar bagi masyarakat miskin dan para bidan PTT yang mengabdi di Desa di seluruh wilayah Kabupaten Konawe. Kebijakan terhadap arah dan sasaran ADD ini sebaiknya dipertahankan dan diperluas dalam program lain yang bersentuhan langsung dengan kebutuhan masyarakat. Misalnya peningkatan Usaha Ekonomi Produktif dalam skala kecil dan menengah dengan memanfaatkan BUMDes sebagai wadah untuk penyaluran ADD tersebut. BUMDes dapat menerima penyertaan modal desa melalui Dana Desa dan Bantuan UEP dari ADD, sehingga dana tersebut menjadi modal desa yang dilakukan secara terus menerus dalam rangka menumbuhkembangkan perekonomian Desa. Pemerintah Kabupaten melakukan pembinaan sekaligus pengawasan bekerja sama dengan Pemerintah Desa dan Lembaga Desa lainnya untuk peningkatan kualitas BUMDes tersebut.

Program ADD untuk pembangunan dapat diperluas untuk mendanai kebutuhan warga miskin yang sampai saat ini belum mempunyai KWH. Dengan demikian masyarakat miskin juga dapat menikmati standar hidup minimal, Kebutuhan MCK bagi rumah tangga miskin dan Sarana Air Bersih yang menunjang kehidupan mereka. Dengan demikian apabila pemenuhan kebutuhan dasar masyarakat semakin baik maka kualitas hidup mereka juga akan lebih baik. Diharapkan dengan kontribusi yang diberikan oleh pemerintah menjadi perangsang/stimulan bagi masyarakat untuk ikut serta dalam pelaksanaan pembangunan, sehingga pelaksanaan prinsip tata kelola penyeneggaraan pemerintahan Desa yang baik dapat diwujudkan melalui peran serta masyarakat, lembaga desa dan pemerintah desa.

\section{KESIMPULAN}

Berdasarkan uraian yang dikemukakan sebelumnya dapat disimpulkan beberapa hal sebagai berikut :

1. Pelaksanaan ADD di Kabupaten Konawe secara umum berpedoman pada regulasi yang diterbitkan oleh Bupati Konawe setiap tahunnya dalam bentuk Peraturan Bupati Konawe;

2. Pelaksanaan ADD selama kurung waktu 4 (empat) tahun terakhir telah memberikan manfaat kepada Pemerintah Desa dan masyarakat Kabupaten Konawe, meskipun ADD dalam bidang pemberdayaan masyarakat nilainya sangat kecil tetapi dampaknya sangat bermafaat bagi kepentingan masyarakat.

3. Pelaksanaan ADD tahun 2017 khususnya program Desa Kampung Perisai sangat membantu dalam pemberdayaan masyarakat terutama masyarakat miskin dan kaum perempuan. Pemberdayaan masyarakat yang menjadi unggulan Pemerintah Kabupaten Konawe adalah Program Bedah Rumah dan UEP.

\section{REKOMENDASI}

Kepada Instansi Teknis dalam hal ini DPMPD Kabupaten Konawe agar dapat memberikan masukan kepada Bupati untuk memaksimalkan UEP melalui BUMDes di setiap Desa untuk menunjang pelaksanaan ekonomi perdesaan baik skala kecil, menengah dan sakal besar. Pelaksanaan kebijakan ekonomi Desa diarahkan kepada BUMDes. Pemerintah Daerah dapat bertindak sebagai pembina dan sekaligus sebagai pengawas dalam pelaksanaan keinerja BUMDes.

\section{DAFTAR PUSTAKA}


Adisasmita, Rahardjo. 2006. Membangun Desa Partisipatif. Yogyakarta: Graha Ilmu

Badan Pusat Statistik. 2016. Kabupaten Konawe dalam Angka (Konawe Regency In Figure). BPS Kabupaten Konawe.

Eko, S. 2004. Reformasi Politik dan Pemberdayaan Masyarakat. Yogyakarta:APMD Press.

Eko, S. 2015. Regulasi Baru, Desa Baru (Ide, Misi dan Semangat UU Desa). Kementerian Desa dan Daerah Teringgal dan Transmigrasi Republik Indonesia: Jakarta

Fahrudin, Adi. 2012. Pemberdayaan, Partisipasi dan Penguatan Kapasitas Masyarakat. Bandung: Humaniora.

Hasan, Engking S. 2002. Strategi Menciptakan Manusia yang Bersumber Daya Unggul. Bandung: Pustaka Rosda Karya.

Hurairah, Abu. 2008. Pengorganisasian dan Pengembangan Masyarakat Model dan Strategi Pembangunan yang Berbasis Kerakyatan. Bandung : Humaniora.

Kurniawan, B. 2015. Desa Mandiri Desa Membangun. Kementerian Desa, Pembangunan Daerah Tertinggal dan Transmigrasi: Jakarta.

Mahfudz. 2009. Analisis Dampak Alokasi Dana Desa (ADD) Terhadap Masyarakat dan Kelembagaan Desa. Jurnal Organisasi dan Manajemen, Volume 5, Nomor 1, Maret 2009, 10-22.

Manolong, E.S.P. 2005. Peran Tokoh Masyarakat dalam Perencanaan Pembanguanan Desa (Suatu Studi di Desa Naha Kecamatan Tabukan Utara Kabupaten Sangihe). GOVERNANCE, 5 (1), 0-10. Diambil dari https://ejournal.unsrat.ac.id/index.php/governance/article/view/1533.

Misno. 2015. Manfaat Alokasi Dana Desa bagi Masyarakat Desa (Studi pada Desa Blankahan Kecamatan Kuala Kabupaten Langkat). Jurnal Perspektif. Volume 8 Nomor 2 Oktober 2015, 539-547.

Rosalina, M., 2013. Kinerja Pemerintah Desa dalam Pembangunan Infrastruktur di Desa Kuala Lapang dan Desa Taras Kecamatan Malinau Barat. Kabupaten Malinau. E-journal Pemerintahan Integratif, 1 (1), 106-120. Diambil dari http:/ejournal.pin.or.id/site/wpconten/uploads/2003/02/02 ejournal Maya_Rosalina (02-08-13-1207-23)

Suhendra, K. 2006. Peranan Birokrasi dalam Pemberdayaan Masyarakat. Bandung: Alfabeta.

Sugiyono. 2012. Metode Penelitian Administrasi. Bandung. Alfa Beta.

Surjono, Agus \& Trilaksono, Nugroho. 2008. Paradigma, Model, Pendekatan Pembangunan dan Pemberdayaan Masyarakat di Era Otonomi Daerah, Malang: Bayu Media Publisihing.

Wahab, Solihin Abdul. 2008. Pengantar Analisis Kebijakan Publik. UPT Penerbitan Universitas Muhammadiyah, Malang.

Wasistiono, Sadu. 2006. Prospek Pengembangan Desa. Bandung: Fokusmedia.

Widjaja, HAW. 2005. Otonomi Desa Merupakan Otonomi yang Asli, Bulat dan Utuh. Jakarta: PT Rajawali Pers.

Winarni, Tri. 2008. Memahami Pemberdayaan Desa Partisipatif dalam Orientasi Pembangunan Masyarakat Desa Menyongsong Abad 21: Menuju Pemberdayaan Pelayanan Masyarakat: Yogyakarta: Aditya Media. 
Wrihatnolo, Randy R. \& Dwidjowijoto, Riant, N. 2006. Kebijakan Publik untuk Negara-Negara Berkembang: Model-Model Perumusan, Implementasi, dan Evaluasi. Jakarta: PT. Elex Media Komputindo.

Wrihatnolo, Randy R. \& Riant Nugroho, D . 2007. Manajemen Pemberdayaan : Sebuah Pengantar dan Panduan untuk Pemberdayan Masyarakat. Jakarta : PT. Elex Media Komputindo.

\section{Peraturan Perundang-Undangan}

Undang-Undang RI Nomor 6 tahun 2014 tentang Desa.

Undang-Undang RI Nomor 9 tahun 2015 tentang Perubahan Atas Kedua Undang-Undang RI Nomor 23 tahun 2014 tentang Pemerintahan Daerah.

Peraturan Pemerintah Republik Indonesia Nomor 60 tahun 2014 tentang Dana Desa yang Bersumber dari Anggaran Pendapatan dan Belanja Negara sebagaimana telah diubah dengan Peraturan Pemerintah Nomor 22 tahun 2015 tentang Perubahan Atas Peraturan Pemerintah Republik Indonesia Nomor 60 tahun 2014 tentang Dana Desa yang Bersumber dari Anggaran Pendapatan dan Belanja Negara.

Peraturan Pemerintah Republik Indonesia Nomor 43 tentang Peraturan Pelaksanaan Undang-Undang Nomor 6 tahun 2014 tentang Desa, sebagaimana telah di ubah menjadi Peraturan Pemerintah Nomor 47 tahun 2015 tentang Perubahan atas Peraturan Pem

Perintah Nomor 43 tahun 2014 tentang Peraturan pelaksanaan Undang-Undang Nomor 6 tahun 2014 tentang Desa.

Peraturan Pemerintah Republik Indonesia Nomor 47 Tahun 2015 Tentang Perubahan Atas Peraturan Pemerintah Nomor 43 Tahun 2014 Tentang Peraturan Pelaksanaan Undang-Undang Nomor 6 Tahun 2014 Tentang Desa

Peraturan Pemerintah Republik Indonesia Nomor 58 tahun 2005 tentang Pengelolaan Keuangan Daerah

Peraturan Menteri Dalam Negeri Republik Indonesia Nomor 113 Tahun 2014 Tentang Pengelolaan Keuangan Desa.

Peraturan Menteri Dalam Negeri Republik Indonesia Nomor 114 Tahun 2014 Tentang Pedoman Pembangunan Desa

Peraturan Bupati Konawe Nomor 5 Tahun 2016 tentang Petunjuk Teknis Pelaksanaan Alokasi Dana Desa Tahun Anggaran 2016.

Peraturan Bupati Konawe Nomor 3A Tahun 2015 tentang Petunjuk Teknis Pelaksanaan Alokasi Dana Desa Tahun Anggaran 2015.

Peraturan Bupati Konawe Nomor 06 tahun 2014 tentang Petunjuk Teknis Pelaksanaan Alokasi Dana Desa Tahun Anggaran 2014.

Peraturan Daerah Kabupaten Konawe Nomor 8 Tahun 2009 tetang Alokasi Dana Desa

Peraturan Daerah Kabupaten Konawe Nomor 31 Tahun 2015 tentang Pengelolaan Keuangan Desa, Kekayaan dan Badan Usaha Milik Desa. 